\title{
EDITORIAL
}

Volume III, No. 1 marks the first issue of IJME published by Palgrave: Macmillan's global academic publishing, in association with Erasmus University Rotterdam. After 2 years of hard work in building up the reputation of this peer-reviewed Journal, owed in no small measure to the diligence and commitment of its Editorial Board, the University sees with a lot of satisfaction the successful fruition of its efforts into what it considers as a landmark in the development of Maritime Economics.

The prestige and networking possibilities of the new publisher, I would dare say one of the most esteemed and historical quality names in global publishing, are expected to give a substantial outreach to the already extensive visibility of the Journal. More importantly, however, it will provide an additional stimulus to researchers to embrace IJME as their preferred publishing outlet for quality maritime research. In this context, we are delighted that IJME has been accepted for inclusion in a number of eminent indices maintained by the American Economic Association's Journal of Economic Literature - EconLit, e-JEL, and JEL on CD.

The inauguration of IJME in 1999 was the culmination of many years of discussions among maritime economists who were, for a long time, feeling the need for a peerreviewed scholarly academic journal able to advance Maritime Economics as a distinct and well-defined branch of applied economics. Ever since, this has become the mission of IJME and its editors. Being fully aware of the significant and most valuable efforts of other publications to gain inroads into the immediate, practical and informational interests and needs of the maritime business professional, IJME decided to limit itself only to the niche of high calibre applied maritime research, mainly of quantitative nature.

However, IJME will also regularly host a special Section B under the heading 'Policy Perspectives'. Papers here, often invited ones from eminent personalities, are refereed in a different way, with the emphasis placed on the paper's strategic policy implications rather than on scientific rigour in a strict sense. Section B is not peerreviewed.

In less than 2 years, this editorial policy orientation of IJME has proven spectacularly correct in many ways. The Journal is now not only required reading in most post-graduate courses but, as a result of the applied character of its papers, it has been warmly adopted by major research institutes, international organisations, governments, transport companies and port authorities all over the world who have also been contributing with influential research papers.

In promoting and strengthening this editorial policy orientation, the new publishers have been found ready to also award two annual 'Palgrave Prizes' for the 'PhD of the Year' and the 'Paper of the Year' (published in IJME). An Editorial Jury decides prizes and the first awards are being planned for December 2001. Exceptionally for this year, eligible PhDs are those successfully defended in 1999 as well as 2000 (for details please contact the editorial office).

Readers will no doubt notice IJME's new editorial structure. As a result of the increased demands of peer-review processes, the old editorial structure has been 
expanded to include 15 new colleagues while, in consultation with the Publishers and after discussions with all members, it was decided to restructure the board in two tiers: an Editorial Board, and an Editorial Committee.

The Editorial Board consists of colleagues expressly expected to actively promote the Journal; solicit good papers; and referee a number of them in the course of the year. The composition of the Board reflects a fair geographical representation as well as distribution of specialisations according to the Journal's areas of interest. Its international orientation is strengthened by the appointment of Regional Editors.

The Editorial Committee consists of distinguished colleagues who although may not have at present the time and/or infrastructure to effectively undertake duties as the above, have nevertheless the willingness and enthusiasm to advise on matters of general editorial policy. Their input is considered invaluable for the future direction and quality of the Journal. Occasionally, they may also be asked to referee papers. Both Board and Committee members receive a copy of the Journal with the compliments of the Publishers and are invited to editorial meetings. Members of both editorial groups are appointed for a renewable period of 2 years.

In addition to its international roster of editors - the Journal's most valuable asset the success of IJME has been the result of the diligent efforts of a great number of people. Amongst them, I am indebted to the Assistant Editor, D. Kontou, for her incessant perseverance on uncompromising quality; Chantal Cheung Tam He, manager of the IAME Permanent Secretariat and of the Erasmus MSc in Maritime Economics and Logistics; all members of the Erasmus Maritime Economics Group; the Management and Finance Office of the Rotterdam School of Economics; the Erasmus Executive Development (EED); and last but not least David Bull, Palgrave Director of Journals, whose enthusiasm in this venture enabled us to make progress in our discussions in record time.

\section{HE Haralambides}

